\title{
The Effect of Philanthropic Activities on Corporate Financial Performance: From the Perspectives of Charity Donation and Volunteer Service
}

\author{
Fangfang Liao \\ College of Economics, Jinan University, Guangzhou, China \\ Email: liaoffang925@qq.com
}

How to cite this paper: Liao, F.F. (2020) The Effect of Philanthropic Activities on Corporate Financial Performance: From the Perspectives of Charity Donation and Volunteer Service. Modern Economy, 11, 96-108.

https://doi.org/10.4236/me.2020.111010

Received: December 17, 2019

Accepted: January 14, 2020

Published: January 17, 2020

Copyright ( 2020 by author(s) and Scientific Research Publishing Inc. This work is licensed under the Creative Commons Attribution International License (CC BY 4.0).

http://creativecommons.org/licenses/by/4.0/

\begin{abstract}
Company can not only make charity donation, but also carry out volunteer service to perform philanthropic responsibilities. So how do company's philanthropic activities affect its financial performance? This paper uses data of Chinese A share listed companies to investigate the effect of philanthropic activities on corporate financial performance by two-stage Heckman selection model. The results show that corporate charity donation has a positive impact on its financial performance, however volunteer service has a negative and significant on it. There are evidences show that as a rational person, companies perform philanthropic responsibilities through charity donations, which can have a better positive impact on companies.
\end{abstract}

\section{Keywords}

Corporate Financial Performance, Charity Donation, Volunteer Service, Two-Stage Heckman Selection Model

\section{Introduction}

Carroll (1991) [1] argued that four kinds of social responsibilities constitute the pyramid of CSR (corporate social responsibility): economic, legal, ethical, and philanthropic. Among them, economic responsibilities are the most basic, while legal responsibilities are second, ethical responsibilities are at the third level, and philanthropy responsibilities are at the top. This paper focuses on the effect of corporate philanthropy responsibilities on its financial performance. As an important component part of CSR, philanthropy responsibilities have always been 
a hot topic in the research of corporate social responsibility and corporate financial performance (CSR-CFP). Base on existing literatures, there are many papers investigate the relationship between corporate charity donation and corporate financial performance, many of them argued that Charity donation is positively correlated with financial performance. Strategic philanthropy Godfrey (2005) [2] argued that there is a positive correlation between charity donation and corporate financial performance. The economic goals held by companies are compatible with philanthropic activities rather than contradictory. Companies participating in philanthropic activities can establish a good reputation, improve their competitiveness, increase product sales, and create more added value.

However, charity donation is not the only way for companies to fulfill their philanthropic responsibilities. Corporate philanthropic activities mainly include charity donation and volunteer service. Company can not only make charity donation, but also carry out volunteer service to perform philanthropic responsibilities. At present, there are few literatures discuss the effect of volunteer service on financial performance. According to the China Charity Development Report 2018, the total amount of social donations in China in the past year is estimated to be 155.8 billion yuan, and the value of volunteer services nationwide is estimated to be 54.8 billion yuan. Corporate charity donations have always been the main force of social donations, but the value of voluntary services also exceeds one third of the total social donations. More and more companies fulfill philanthropic responsibilities by carrying out volunteer services. For example, a number of airlines volunteered to provide disaster relief lines to transport relief supplies and evacuate victims in the earthquake relief, medical enterprises provide free health check for residents in the community, and some companies organize employees to donate blood voluntarily. Companies carry out various volunteer services, which can also enhance the reputation of enterprises, and bring strategic value to enterprises.

Therefore, from the perspectives of charity donation and volunteer service, this paper uses the data of Chinese A share listed companies from 2008 to 2014 to verify the effect of charity donations and volunteer services on corporate financial performance. It's conducive to answering the questions concerned by entrepreneurs: can volunteer service of companies bring certain returns? And can volunteer service and donation bring the same effect? This paper has some practical significance in answering these questions and enriches the corporate philanthropy research. If corporate philanthropy can bring higher corporate financial performance, it will encourage enterprises to further integrate charity planning into corporate strategic planning and integrate philanthropy programs into corporate business model.

\section{Theoretical Analysis and Empirical Strategy}

\subsection{Theoretical Analysis}

Base on the existing literatures, charitable activities is positively correlated, nega- 
tively correlated and uncorrelated with corporate financial performance. But a majority of literatures argued that the relationship between them is positively correlated. This paper tries to analyze the theories from indirect and direct aspects.

\subsubsection{Indirect Effects}

From the perspective of strategic charity (Smith, 1994) [3], although some charitable activities cannot enable companies to immediately obtain tangible, clear and independent exchange value, they can help enterprises to obtain intangible strategic assets, including organizational reputation (Fombrun et al., 2000) [4], trust (Zucker, 1986) [5], political relations (Dai et al., 2014) [6] etc., thus create a good competitive advantage for companies (Porter \& Kramer, 2002) [7]. Zhong (2007) [8] argued that corporate philanthropic activities actually play a role in maintaining and increasing the value of companies, and that corporate financial performance can be indirectly improved by improving the relationship between companies and stakeholders. Du \& Feng (2010) [9] empirical results showed that the accounting performance and market performance of companies were significantly improved after charity donations. Corporate philanthropic activities can enhance corporate reputation, maintain good relationship with stakeholders, expand product diversity in the eyes of stakeholders, especially customers, enhance customer demand for products, and increase sales revenue. The positive corporate culture formed by corporate philanthropic activities will infect employees with the same values, increase their loyalty and improve their work efficiency. Enterprises actively carry out various charitable activities, can maintaining good government-enterprise relationship and market reputation, which is conducive to companies to obtain or strengthen monopoly position, enhance strategy and competitive environment.

\subsubsection{Direct Effects}

Companies can make more consumers know about them and its products through charity donations and volunteer services, and then transfer from the consumption of similar substitute products to their products. For service companies, they should organize voluntary activities to get in close contact with consumers and understand their needs, so as to optimize their market services more pertinently. Wang \& Pan (2011) [10] based on the data of Chinese listed companies on charitable donations from 2002 to 2008 , found that the higher degree of stakeholder satisfaction, the more obvious the effect of charitable donation on enhancing corporate financial performance. Lu \& Liu (2012) [11] argued that the donation significantly promotes the sales growth rate, and the positive correlation between the donation behavior of companies directly contacting consumers and sales growth is stronger. Participation in volunteer services can enhance employees' cooperation and enthusiasm, increase employees' sense of responsibility, and improve the community environment (Porter \& Kramer, 2006) [12]. The strategic philanthropic activities of companies can also improve 
the development environment of relevant industries, not only promote the development of relevant industrial clusters, but also further promote the development of supporting industries.

\subsection{Data and Sources}

Because the charity data of Chinese A listed companies have only been disclosed normatively since 2006, and the CSMAR database only discloses the detailed information of corporate social responsibility projects from 2008 , this paper chooses 2008-2014 as the research period. This paper takes all Chinese A share listed companies as original samples with the exception of: financial companies, ST and PT listed companies, companies with clearly wrong articulation on charity donation, and companies with insufficient data of each control variable. The data in this paper all are from CSMAR database, and the detailed information of corporate charity activities is from the CSR sub-database of CSMAR.

\subsection{Empirical Models and Variable Declaration}

At present, most of the literatures on this kind of problems only selected companies which participating in charity activities as the research objects. Therefore, this paper adopts the Heckman two-stage model to test and redress the sample selection bias. The first stage is probit model of company charity activities decision-making. The second stage is the performance model of the effect of corporate charity activities on its financial performance. In the first stage, all companies (including those participating in charity activities and those non-participating in charity activities) are taken as the research objects, and the dummy variable that if the company participated in charity activities the value is 1 otherwise is 0 as the dependent variable to conduct probit regression analysis and find out the Inverse Mill's Ratio. In the model of the second stage, companies participating in charity activities are taken as the research objects, corporate financial performance is taken as the dependent variable, and the Inverse Mill's Ratio calculated in the first stage is taken as the control variable and add into the regression model of the second stage to study the effect of charity activities on financial performance. If the regression coefficient of Inverse Mill's Ratio is significant, it indicates that there is a problem of sample selection bias, which needs to be corrected by the Heckman two-stage model.

Therefore, this paper will measure philanthropic responsibility from two perspectives: one is charity donation; the other is volunteer service. Heckman model (1) and (2) were set up to test the effect of charity donation on corporate financial performance, the specific model is as follows:

The first stage of Heckman model:

$$
\begin{aligned}
\text { dona_cd }_{i, t}= & \beta_{0}+\beta_{1} \mathrm{ROE}_{i, t}+\beta_{2} \operatorname{lev}_{i, t}+\beta_{3} \text { size }_{i, t}+\beta_{4} \text { Inpind_dona }_{i, t} \\
& +\beta_{5} \mathrm{SOE}_{i, t}+\vartheta_{t}+\mu_{i, t}
\end{aligned}
$$


The second stage of Heckman model:

$$
\mathrm{ROE}_{i, t}=\beta_{0}+\beta_{1} \ln \text { dona }_{i, t}+\beta_{2} \mathrm{lev}_{i, t}+\beta_{3} \mathrm{IMR}+\beta_{4} \mathrm{SOE}_{i, t}+\vartheta_{t}+\mu_{i, t}
$$

Heckman model (3) and (4) were set up to test the effect of volunteer service on corporate financial performance, the specific model is as follows:

The first stage of Heckman model:

$$
\begin{aligned}
\mathrm{N}_{-} \mathrm{cd}_{i t}= & \alpha_{0}+\alpha_{1} \mathrm{ROE}_{i, t}+\alpha_{2} \operatorname{lev}_{i, t}+\alpha_{3} \operatorname{size}_{i, t}+\alpha_{4} \operatorname{lnpind} \mathrm{N}_{i, t} \\
& +\alpha_{5} \mathrm{SOE}_{i, t}+\vartheta_{t}+\varepsilon_{i, t}
\end{aligned}
$$

The second stage of Heckman model:

$$
\mathrm{ROE}_{i, t}=\alpha_{0}+\alpha_{1}{\ln \_\mathrm{N}_{i, t}}+\alpha_{2} \mathrm{lev}_{i, t}+\alpha_{3} \mathrm{IMR}+\alpha_{4} \mathrm{SOE}_{i, t}+\vartheta_{t}+\varepsilon_{i, t}
$$

In the first stage, dona_cd and N_cd are the dependent variables which are the dummy variables. If the company participated in charity donation the value of dona_cd is 1 otherwise is 0 . N_cd means whether the listed company has organized voluntary service activities, according to the information of CSR sub-database of CSMAR, this paper assumes that if the company carry out volunteer services published in the annual report the value of N_cd is 1 otherwise is 0 . In the second stage, the dependent variable is Return on Equity (ROE) of listed companies to measure the corporate financial performance, and the source of it is CSMAR database.

This paper selects the logarithm of total charitable donations (ln_dona) published in the annual report of listed companies and the logarithm of annual voluntary projects ( $\left.\mathrm{ln} \_\mathrm{N}\right)$ calculated according to the specific voluntary activities in the annual report of listed companies as the independent variable. ln_dona is used to measure corporate charitable donation, and $\mathrm{ln} \_\mathrm{N}$ is used to measure corporate volunteer service.

Control variables include liability-assets ratio (lev), the ownership of companies (SOE), if the company is a state-owned enterprise, the value of SOE is 1 otherwise is 0 , the logarithm of industry average donation amount (lnpind_dona), the logarithm of industry average volunteer service project numbers every year (lnpind_N), the logarithm of company total assets (size) and the virtual variable of year $\left(\vartheta_{t}\right)$. Because the premise of the two-stage Heckman selection model is that one or more variables must be found that can affect the independent variable, but have no effect on the observed dependent variable. Whether a company participates in charitable donation will be affected by the charitable donation of other enterprises in the same industry, but the average charitable donation of the industry has no direct impact on financial performance of the company (Galaskiewicz and Burt, 1997) [13]. Therefore, in this paper, lnpind_dona and lnpind_N are taken as instrumental variables and put into the models (1) and (3) of the first stage of Heckman respectively.

\section{Empirical Results and Analysis}

\subsection{Statistical Description}

Table 1 is a statistical description of the first stage of Heckman model variables 
in this paper. In the whole samples, the ROE mean of Chinese A listed companies is $8.57 \%$ and the standard deviation is 10.53 , which indicates that there is a large gap in the financial performance of the companies between the samples, and the minimum value is $-57.35 \%$ and the maximum value is $43.14 \%$. In order to eliminate the influence of outliers, this paper had been removed one percent of the minimum and maximum of the sample. The mean of $\ln$ _dona is 1.39 and the standard deviation is 4.25 , indicating that the amount of charity donations between different listed companies are quite different. The mean value, standard deviation and maximum value of annual voluntary projects of enterprises are $0.88,3.49$ and 67 respectively. The reason may be that there are few companies that publish voluntary service activities in the annual report, and there is heterogeneity among different samples and some companies may not prefer voluntary service. In terms of control variables, the difference between industry average donations and industry average number of volunteer projects was small. The standard deviation of company size and lev is relatively small, which indicates that the size and asset-liability ratio of listed companies are not so different.

Table 2 is a statistical description of the first stage of Heckman model variables in this paper. In the second stage of Heckman, this paper respectively examines the impact of charitable activities (include charity donation and volunteer service) on corporate financial performance. Therefore, the sample of companies participating in donation (dona_cd $=1$ ) is defined as charity donation sample and used as the sample of model (2). When the value of N_cd is 1 , the sample is defined as of volunteer service sample, which is the sample of model (4). In the charity donation sample, the mean of ROE is significantly higher than that of the whole sample, and the standard deviation of the total donations amount is also significantly smaller. In the volunteer service sample, similarly, the average ROE is larger than that of the whole sample. However, the standard deviation of the annual number of voluntary projects 7.15 , indicating that there is difference in the number of voluntary services organized by different companies every year.

Table 1. Variables statistical description of the first stage of Heckman model.

\begin{tabular}{|c|c|c|c|c|c|}
\hline Variables & Indicator & Mean & Std. & Min. & Max \\
\hline ROE & Return on equity & 8.57 & 10.53 & -57.35 & 43.14 \\
\hline ln_dona & $\ln$ (Donation amounts) & 1.39 & 4.25 & 0 & 20.95 \\
\hline $\mathrm{N}$ & Number of volunteer service projects & 0.88 & 3.49 & 0 & 67 \\
\hline size & $\ln$ (total assets) & 21.79 & 1.32 & 13.08 & 28.51 \\
\hline lev & Asset-liability ratio & 0.46 & 1.13 & 0 & 96.96 \\
\hline SOE & The ownership of company & 0.40 & 0.49 & 0 & 1 \\
\hline lnpind_dona & $\ln$ (industry average donation amounts) & 12.50 & 1.56 & 7.46 & 18.65 \\
\hline pind_N & $\begin{array}{l}\text { Industry average volunteer service } \\
\text { project numbers }\end{array}$ & 0.87 & 0.92 & 0 & 10.40 \\
\hline
\end{tabular}


Table 2. Variables statistical description of the second stage of Heckman model.

\begin{tabular}{|c|c|c|c|c|}
\hline \multicolumn{5}{|c|}{ Charity donation sample (dona_cd $=1$ ) } \\
\hline Variables & Mean & Std. & Min. & Max. \\
\hline ROE & 12.03 & 9.45 & -54.37 & 42 \\
\hline ln_dona & 14.13 & 1.90 & 8.52 & 20.95 \\
\hline size & 23.10 & 1.57 & 18.76 & 28.51 \\
\hline lev & 0.50 & 0.20 & 0.01 & 0.87 \\
\hline SOE & 0.51 & 0.50 & 0 & 1 \\
\hline lnpind_dona & 13.08 & 1.65 & 7.46 & 18.65 \\
\hline \multicolumn{5}{|c|}{ Volunteer service sample $\left(\mathrm{N} \_c d=1\right)$} \\
\hline Variables & Mean & Std. & Min. & Max. \\
\hline ROE & 11.15 & 9.55 & -54.37 & 42 \\
\hline $\mathrm{N}$ & 5.72 & 7.15 & 1 & 67 \\
\hline ln_dona & 8.33 & 7.10 & 0 & 20.95 \\
\hline size & 23.01 & 1.49 & 18.76 & 28.51 \\
\hline lev & 0.51 & 0.20 & 0.01 & 0.93 \\
\hline SOE & 0.57 & 0.50 & 0 & 1 \\
\hline pind_N & 1.30 & 1.21 & 0.03 & 10.40 \\
\hline
\end{tabular}

\subsection{Empirical Analysis}

\subsubsection{How Does the Charity Donation Affect Financial Performance?}

As show in the first column of Table 3, ROE is adopted as the financial performance index in the probit regression. In model (1), the time fixed effect was controlled. The results show that the regression coefficients of ROE, size and lnpind_dona are all significantly positive, which is basically consistent with the expectation, indicating that the better the corporate financial performance is, the larger the company scale is, and the larger the industry average donation scale is, the more likely the company is to participate in charitable donation. The regression coefficient of lev is significantly negative, indicating that the lower financial leverage a company has, the more likely it is to make charitable donations. The regression coefficient of $\mathrm{SOE}$ is negative, but not significant, indicating that the ownership of a company has no significant impact on the charity donation.

In order to test and correct the sample selection bias, the Inverse Mills Ratio (IMR) calculated by model (1) in Table 3 is added into the regression of the second stage as a control variable. As show in the second column of Table 3, the results show that the regression coefficient of IMR is significantly negative, which indicate that only companies participating in charitable donation as research samples would lead to the problem of sample selection bias. Therefore, 
the Heckman two-stage model is needed to correct the problem of sample selection. At same time, in order to overcome the influence of heteroscedasticity on regression results, the robust standard deviation is selected for processing. The regression results of model (2) show that the regression coefficient of ln_dona is 0.4599 , which is significant and positive. The sample evidence supports that corporate charitable donation has an obvious positive effect on corporate financial performance. From the perspective of the coefficient of control variables, the asset-liability ratio is negatively correlated with its financial performance, which indicates that the higher the asset-liability ratio is, the bigger the risk is. The regression coefficient of SOE is significantly negative, indicating that the performance of non-state-owned enterprises is better than that of state-owned enterprises on the whole, and private enterprises are more dynamic.

Table 3. The effect of charity donation on corporate financial performance.

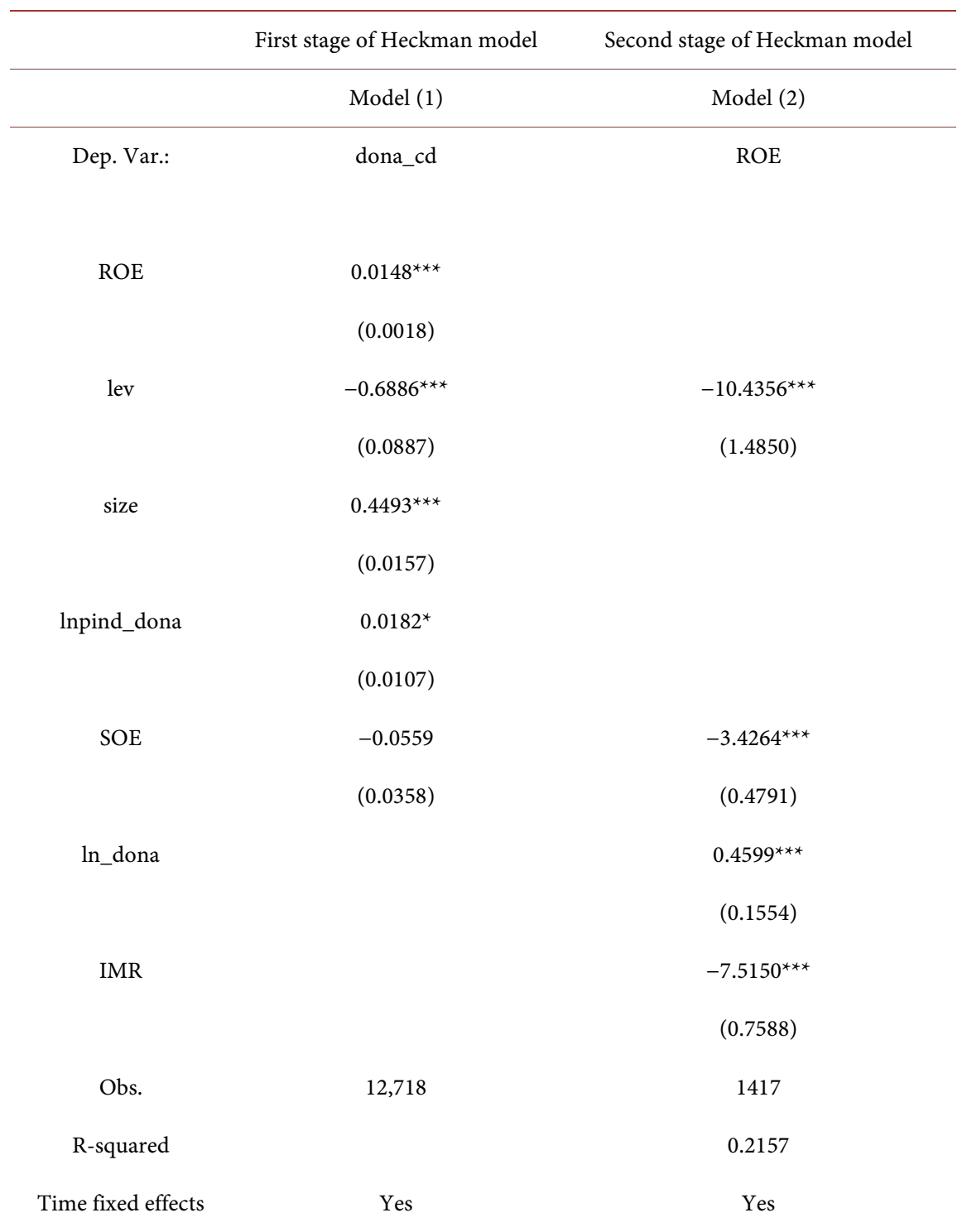

Note: Standard errors in parentheses. ${ }^{*} \mathrm{p}<0.1,{ }^{* *} \mathrm{p}<0.05,{ }^{* *} \mathrm{p}<0.01$. 


\subsubsection{How Does the Volunteer Service Affect Financial Performance?}

As show in the first column of Table 4, ROE is used as the financial performance index in the probit regression. In model (3), the time fixed effect was controlled. Results show that the regression coefficients of ROE, size and lnpind_N were all significantly positive, indicating that the better business financial performance, the bigger the scale, the more industry average volunteer service activities, the more the chance of company to carry out the volunteer service activities. The regression coefficient of lev is significantly negative, indicating that the lower the financial leverage of enterprises, the more likely to carry out volunteer services. Different from the impact of charitable donation on financial performance, the regression coefficient of SOE is significantly positive, indicating that state-owned enterprises are more likely to carry out volunteer service ac.

Table 4. The effect of volunteer service on corporate financial performance.

\begin{tabular}{|c|c|c|}
\hline & First stage of Heckman model & Second stage of Heckman model \\
\hline & Model (3) & Model (4) \\
\hline Dep. Var.: & N_cd & ROE \\
\hline ROE & $\begin{array}{l}0.0125^{* * *} \\
(0.0015)\end{array}$ & \\
\hline lev & $\begin{array}{c}-0.5326^{* * *} \\
(0.0789)\end{array}$ & $\begin{array}{c}-10.8816^{* * *} \\
(1.2753)\end{array}$ \\
\hline size & $\begin{array}{l}0.4677^{\star * *} \\
(0.0147)\end{array}$ & \\
\hline lnpind_N & $\begin{array}{l}0.0880^{* * *} \\
(0.0205)\end{array}$ & \\
\hline SOE & $\begin{array}{l}0.1224^{* * *} \\
(0.0312)\end{array}$ & $\begin{array}{c}-4.2501^{* * *} \\
(0.4352)\end{array}$ \\
\hline $\ln \_\mathrm{N}$ & & $\begin{array}{c}-0.5722^{\star *} \\
(0.2300)\end{array}$ \\
\hline ln_dona & & $\begin{array}{l}0.0921^{* * *} \\
(0.0292)\end{array}$ \\
\hline IMR & & $\begin{array}{c}-8.1714^{* * *} \\
(0.6086)\end{array}$ \\
\hline Obs. & 13,597 & 2226 \\
\hline R-squared & & 0.1763 \\
\hline Time fixed effects & Yes & Yes \\
\hline
\end{tabular}

Note: Standard errors in parentheses. ${ }^{*} \mathrm{p}<0.1,{ }^{* *} \mathrm{p}<0.05,{ }^{* * *} \mathrm{p}<0.01$. 
As show in the second column of Table 4, similarly, in order to test and correct the sample selection bias, IMR calculated by model (1) in Table 4 is added to the regression in the second stage as a control variable. The results show that the regression coefficient of IMR is significantly negative, indicating that only companies with volunteer service activities are used as research samples, which would lead to the problem of sample selection bias. Therefore, the Heckman two-stage model is needed to correct the problem of sample selection. At the same time, in order to overcome the influence of heteroscedasticity on regression results, the robust standard deviation was selected for processing. The regression results of model (4) show that, the regression coefficient of $\ln \_\mathrm{N}$ is -0.5722 , which is significantly negative. This sample evidence supports that more volunteer service activities organized by companies will have a negative impact on their financial performance. Although enterprise organize voluntary service can, like charity donation, enhance the reputation of the enterprise, help the enterprise has the better positive image, but the management needs to consider that organization staff to carry out volunteer service, need to suspend part of the employee to work, also need to invest a lot of labor cost and material cost, will have a negative impact to enterprise's production and operation activities.

\subsection{Robustness Test}

This paper also tests the stability of the empirical results. The results of Table 1 and Table 2 show that, the regression coefficient of lev is significantly negative, indicating that the lower the financial leverage of the company is, and the more possible the company to participate charity donation and carry out volunteer service activities. Therefore, in order to avoid the impact of the corporate samples with high financial leverage on the accuracy of model estimation. This paper adopts the samples with "lev $<1$ " to repeat the above empirical process, so as to solve the problems mentioned above. The results are shown in Table 5 and Table 6 which are not materially different from the Table 1 and Table 2 .

Table 5. Robustness test: The effect of charity donation on corporate financial performance.

\begin{tabular}{ccc}
\hline & First stage of Heckman model & Second stage of Heckman model \\
\hline Dep. Var.: & dona_cd $(1)$ & Model (2) \\
ROE & $0.0148^{* * *}$ & \\
& $(0.0018)$ & \\
lev & $-0.6868^{* * *}$ & $-10.4457^{* * *}$ \\
& $(0.0890)$ & $(1.4855)$ \\
size & $0.4490^{* * *}$ & \\
& $(0.0157)$ & \\
lnpind_dona & $0.0182^{*}$ & \\
\hline
\end{tabular}




\section{Continued}

\begin{tabular}{ccc}
\hline SOE & $(0.0107)$ & \\
& -0.0558 & $-3.4273^{* * *}$ \\
ln_dona & $(0.0358)$ & $(0.4791)$ \\
& & $0.4594^{* * *}$ \\
IMR & & $(0.1554)$ \\
& & $-7.5217^{* * *}$ \\
R-squared & & $(0.7591)$ \\
Time fixed effects & Yes & 0.2158 \\
\hline
\end{tabular}

Note: Standard errors in parentheses. ${ }^{*} \mathrm{p}<0.1,{ }^{* *} \mathrm{p}<0.05,{ }^{* * *} \mathrm{p}<0.01$.

Table 6. Robustness test: The effect of volunteer service on corporate financial performance.

\begin{tabular}{|c|c|c|}
\hline & First stage of Heckman model & Second stage of Heckman model \\
\hline & Model (3) & Model (4) \\
\hline Dep. Var.: & N_cd & ROE \\
\hline ROE & $\begin{array}{l}0.0125^{* * *} \\
(0.0015)\end{array}$ & \\
\hline lev & $\begin{array}{c}-0.5288^{* * *} \\
(0.0795)\end{array}$ & $\begin{array}{c}-10.9051^{\star * *} \\
(1.2761)\end{array}$ \\
\hline size & $\begin{array}{c}0.4672^{\star * *} \\
(0.0147)\end{array}$ & \\
\hline lnpind_N & $\begin{array}{l}0.0881^{* * *} \\
(0.0205)\end{array}$ & \\
\hline SOE & $\begin{array}{c}0.1226^{\star * *} \\
(0.0312)\end{array}$ & $\begin{array}{c}-4.2534^{* * *} \\
(0.4352)\end{array}$ \\
\hline $\ln \_N$ & & $\begin{array}{l}-0.5731^{\star *} \\
(0.2300)\end{array}$ \\
\hline ln_dona & & $\begin{array}{l}0.0920^{* * *} \\
(0.0292)\end{array}$ \\
\hline IMR & & $\begin{array}{c}-8.1843^{* * *} \\
(0.6091)\end{array}$ \\
\hline R-squared & & 0.1764 \\
\hline Time fixed effects & Yes & Yes \\
\hline
\end{tabular}

Note: Standard errors in parentheses. ${ }^{*} \mathrm{p}<0.1,{ }^{* *} \mathrm{p}<0.05,{ }^{* *} \mathrm{p}<0.01$. 


\section{Conclusion}

There is a significant positive correlation between corporate charity donation and financial performance. Appropriate and rational decision of charity donation can bring good reputation to the company, improve the recognition and acceptance of the company among the customer group, enhance the sense of identity and loyalty of employees, so as to improve production efficiency and increase financial performance. In the long run, there is a significant negative correlation between the number of volunteer service projects and enterprise performance, which indicates that if enterprises spend a lot of labor cost and material cost to organize more volunteer projects, they will put the cart before the horse and have a negative impact on their production and operation activities. Whether the influence mechanism is similar to that of charity donation on corporate performance is worth further study.

\section{Conflicts of Interest}

The author declares no conflicts of interest regarding the publication of this paper.

\section{References}

[1] Carroll, A.B. (1991) The Pyramid of Corporate Social Responsibility: Toward the Moral Management of Organizational Stakeholders. Business Horizons, 34, 39-48. https://doi.org/10.1016/0007-6813(91)90005-G

[2] Godfrey, P.C. (2005) The Relationship Between Corporate Philanthropy and Shareholder Wealth: A Risk Management Perspective. Academy of Management Review, 30, 777-798. https://doi.org/10.5465/amr.2005.18378878

[3] Smith, C. (1994) The New Corporate Philanthropy. Harvard Business Review, 72, 105-116.

[4] Fombrun, C.J., Gardberg, N.A. and Barnett, M. (2000) Opportunity Platforms and Safety Nets: Corporate Citizenship and Reputational Risk. Business and Society Review, 105, 85-106. https://doi.org/10.1111/0045-3609.00066

[5] Zucker, L.G. (1986) Production of Trust: Institutional Sources of Economic Structure. Research in Organizational Behavior, 8, 53-111.

[6] Dai, Y.Y., Pan, Y. and Feng, S. (2014) Are Chinese Enterprises' Charitable Donations "Political Contributions"? Evidence from the Replacements of the Municipal Party Secretaries. Economic Research Journal, 2, 76-88.

[7] Porter, M.E. and Kramer, M.R. (2002) The Competitive Advantage of Corporate Philanthropy. Harvard Business Review, 80, 56-68.

[8] Zhong, H.W. (2007) The Synthetic Analysis on the Functions of Corporate Philanthropy. China Industrial Economy, 2, 77-85.

[9] Du, X.Q. and Feng, W.T. (2012) Female Managers, Institutional Environment and Corporate Charitable Donation: Evidence from Chinese Capital Market. Economic Management, 11, 64-74.

[10] Wang, D.X. and Pan, Q. (2011) Does Corporate Philanthropy Bring about Corporate Value: The Empirical Evidence Using Stakeholder Satisfaction as a Moderating Variable from Listed Companies. China Industrial Economics, 7, 118-128. 
[11] Lu, Z.W. and Liu, C.L. (2012) Research the Impact of Corporate Philanthropy Giving on Firm Financial Performance: Based on the Consumers' Perspective. Journal of Shanxi Finance and Economics University, 2, 81-88.

[12] Porter, M.E. and Kramer, M.R. (2006) Strategy and Society: The Link between Competitive Advantage and Corporate Social Responsibility. Harvard Business Review, 84, 78-92.

[13] Galaskiewicz, J. and Burt, R.S. (1991) Interorganization Contagion in Corporate Philanthropy. Administrative Science Quarterly, 36, 88-105.

https://doi.org/10.2307/2393431 